\title{
Factors affecting maximal acid secretion
}

\author{
H. G. DesaI \\ M.D.(Bom.) \\ Assistant Physician, B.Y.L. Nair Charitable Hospital, Bombay, India
}

\begin{abstract}
Summary
The mechanisms by which different factors affect the maximal acid secretion of the stomach are discussed with particular reference to nationality, sex, age, body weight or lean body mass, procedural details, mode of calculation, the nature, dose and route of administration of a stimulus, the synergistic action of another stimulus, drugs, hormones, electrolyte levels, anaemia or deficiency of the irondependent enzyme system, vagal continuity and parietal cell mass.
\end{abstract}

\section{Introduction}

Administration of a large dose of histamine under cover of an antihistamine makes it possible to judge the maximal acid secretory capacity of the stomach (Kay, 1953). Various factors were shown to affect the maximal acid secretion. For correct interpretation of the results of gastric secretory function, a proper understanding of the different mechanisms by which these various factors affect maximal acid secretion is essential. In this communication, an attempt is made to provide these data.

\section{Nationality}

The values of maximal acid output (MAO) on the augmented histamine test (AHT) both in male control subjects and patients with duodenal ulcer from India were lower compared with those reported for subjects from western populations (Table 1). Since MAO and parietal cell mass (PCM) show a good correlation (Card \& Marks, 1960; Marks, Komorov \& Shay, 1960; Myren \& Semb, 1962) this observation indicated that Indian subjects have a smaller PCM than that of western subjects (Hussain 1965; Kedarnath, Paul \& Garg, 1965). However, the administration of a fixed dose of histamine $(2.0 \mathrm{mg} / \mathrm{hr}$ to subjects weighing less than $50 \mathrm{~kg})$ on the histamine-infusion test (HIT) to control subjects frem India showed values of acid output comparable with those reported for western subjects (Lawrie \& Forrest, 1965; Desai, Borkar \& Jeejeebhoy, 1967b). The low values of MAO on AHT in Indian subjects are thus due to the administration of a smaller dose of histamine calculated in relation to their lower body weights.

\section{Sex}

The MAO on AHT was found to be lower in females compared with that in males (Kay, 1953; Murray, Erskine \& Fielding, 1957; Marks \& Shay, 1959; Baron, 1963a; Vakil \& Mulekar, 1965; Bank, Marks \& Groll, 1966a; Madangopalan, Subramaniam \& Saroja, 1967). Since the MAO and body weight showed good correlation (Baron, 1964; Ghai et al., 1965; Vakil \& Mulekar, 1965), the low values in females were explained by their lower body weight. In contrast, values of acid output on HIT were comparable in control subjects of both sexes (Lawrie \& Forrest, 1965; Desai et al., 1967b). In all probability, the low values of MAO on AHT in female subjects are due to the administration of a smaller dose of histamine in relation to their lower body weight.

\section{Age}

The values of MAO decrease with advancing age (Baron, 1963a; Vakil \& Mulekar, 1965). The higher incidence of chronic gastritis in elderly subjects probably explains this finding (Williams, 1950; Coghill, 1960).

\section{Body weight or lean body mass}

A good correlation was observed between MAO and body weight in subjects with average body weight of less than $60 \mathrm{~kg}$-children, $25.3 \mathrm{~kg}$ (Ghai et. al., 1965); males and females from India, $50 \mathrm{~kg}$ (Vakil \& Mulekar, 1965); females from Britain, $58.4 \mathrm{~kg}$ (Baron, 1964) - but not in subjects with 
TABLE 1. Values of acid output in male control subjects and duodenal ulcer patients from India and Western populations

\begin{tabular}{|c|c|c|c|c|}
\hline & \multirow{2}{*}{ Reference } & \multirow{2}{*}{ Place } & \multicolumn{2}{|c|}{ Maximal acid output $(\mathrm{mEq} / \mathrm{hr})$} \\
\hline & & & Control subjects & Duodenal ulcer \\
\hline 1. & Kay (1953) & Glasgow, U.K. & $22 \cdot 4$ & $37 \cdot 5$ \\
\hline 2. & Bruce et al. (1959) & Edinburgh, U.K. & $22 \cdot 2$ & $37 \cdot 0$ \\
\hline 3. & Marks \& Shay (1959) & Philadelphia, U.S.A. & $23 \cdot 2$ & $39 \cdot 6$ \\
\hline 4. & Baron $(1963 a, b)$ & London, U.K. & $17 \cdot 1$ & $34 \cdot 2$ \\
\hline 5. & de Moura \& Correia (1964) & Lisbon, Portugal & $16 \cdot 1$ & $36 \cdot 2$ \\
\hline 6. & Bank et al. (1966a) & Cape Town, S. Africa & $22 \cdot 6$ & $31 \cdot 0$ \\
\hline 7. & Kedarnath et al. (1965) & Kanpur, India & $16 \cdot 9$ & $26 \cdot 0$ \\
\hline 8. & Raju et al. (1965) & Vellore, India & $17 \cdot 0$ & $25 \cdot 0$ \\
\hline 9. & Vakil \& Mulekar (1965) & Bombay, India & $12 \cdot 2$ & $17 \cdot 9$ \\
\hline 10. & Cowan, Joseph \& Satija (1966) & Ludhiana, India & $12 \cdot 0$ & $19 \cdot 0$ \\
\hline 11. & Madangopalan et al. (1967) & Madras, India & $10 \cdot 1$ & $20 \cdot 1$ \\
\hline
\end{tabular}

average body weight of more than $60 \mathrm{~kg}$-males from Britain $67.9 \mathrm{~kg}$ (Baron, 1964). The observation that the conventional dose $(0.04 \mathrm{mg} / \mathrm{kg}$ body weight $)$ of histamine acid phosphate provides an inadequate stimulus to the PCM of subjects weighing less than $60 \mathrm{~kg}$ suggests that correlation in these subjects could be an artefact resulting from the smaller and inadequate doses of histamine administered in relation to their lower body weight. It is apparent that the lower the body weight, the smaller the dose of histamine administered and the lower the acid secretion. In fact, administration of a fixed and adequate dose of histamine $(2.0 \mathrm{mg} / \mathrm{hr}$ in subjects weighing less than $50 \mathrm{~kg}$ ) to control subjects from India and the conventional dose of histamine to subjects from Britain did not show any correlation between acid output on HIT and body weight (Lawrie \& Forrest, 1965; Desai et al., 1968a).

Recently, a good correlation was reported between the MAO on AHT and the lean body mass (Hume $\&$ Melrose, 1967). This correlation as well might be due to the administration of a dose of histamine related to body weight and is hence not conclusive. To establish such a correlation, acid output should be measured by administering a fixed and adequate dose of histamine to all subjects irrespective of their body weight (Desai et al., 1968a).

\section{Procedural details}

\section{Screening of the tube}

In several studies 'blind' placement of the tube was found to be unsatisfactory (Levine et al., 1948; James \& Pickering, 1949; Callender, Retief \& Witts, 1960; Baron, 1963a; Vakil \& Mulekar, 1965) and fluoroscopic placement must be considered obligatory. Recently screening of the tube was cmitted in some studies (Johnston, Goligher \& Duthie, 1966) wh:ch, of course, is a retrograde step.

\section{Aspiration}

Continuous aspiration is recommended in order to avoid the effect of gastric emptying on total collection. Suction with a syringe is preferred to the use of a low-pressure suction pump as it results in larger collections (Johnston \& McGraw, 1958) and also because blockage of the tube is immediately noted and corrected by the technician.

\section{Titration}

Titration to neutrality ( $\mathrm{pH} 7$ ) is most accurate electrometrically (using glass electrode $\mathrm{pH}$ meter) while end-point with phenolphthalein is at times difficult to judge. It is not known whether results are significantly altered by using either of these methods.

\section{Mode of calculation}

The values of MAO on AHT are calculated in five different ways: (i) 0-60 min ('whole hour') (Card \& Marks, 1960); (ii) 0-45 min $\times 4 / 3$ (Ball, 1961); (iii) 15-45 min ('mid-half hour') $\times 2$ (Kay, 1953); (iv) two successive 15-min peaks ('peak halfhour') $\times 2$ (Baron, 1963a); and (v) peak $15 \mathrm{~min} \times 4$ (Baron, 1963a). The values are lowest with 'whole hour' and increase significantly if calculated by different ways in the order given (Baron, 1963a). In contrast, significant differences were not observed on calculating the values by methods (i), (iii) and (iv) (Abernethy et al., 1967). The values of acid output on HIT are calculated for $1 \mathrm{hr}$ (Lawrie, Smith \& Forrest, 1964) or for peak $15 \mathrm{~min}$ (Johnston et al., 1966) after a 'steady rate' of secretion is reached.

\section{Stimulus}

\section{Nature of the stimulus}

At present, histamine (Kay, 1953), histalog (Rosiere \& Grossman, 1951), gastrin (Makhlouf, MacManus \& Card, 1964b), pentagastrin (Makhlouf et al., 1966) or tetragastrin (Koster, Rodbro \& Peterson, 1968) are used to judge the PCM while crystalline insulin (Hollander, 1946) or 2-deoxy-Dglucose (an analogue of glucose) are administered intravenously to judge vagal continuity (Duke, Hirschowitz \& Sachs, 1965; Thomas \& Duthie, 1968). The MAO observed with any one stimulus, 
TABLE 2. Minimal doses of different stimulants producing maximal acid secretion

\begin{tabular}{|c|c|c|c|c|}
\hline \multirow{3}{*}{ Stimulus } & \multicolumn{4}{|c|}{ Minimal dose secreting maximal acid secretion } \\
\hline & \multicolumn{2}{|c|}{ Dose } & \multicolumn{2}{|c|}{ References } \\
\hline & Subcutaneous & Intravenous & Subcutaneous & Intravenous \\
\hline $\begin{array}{l}\text { Histamine acid } \\
\text { phosphate }\end{array}$ & $40 \mu \mathrm{g} / \mathrm{kg}$ & $\begin{array}{l}40 \mu \mathrm{g} / \mathrm{kg} / \mathrm{hr} \\
24 \mu \mathrm{g} / \mathrm{kg} / \mathrm{hr}\end{array}$ & $\begin{array}{l}\text { Murray et al. }(1957), \text { Koster } \\
\& \text { Christiansen }(1966)\end{array}$ & $\begin{array}{l}\text { Lawrie et al. (1964), Johnstcn } \\
\text { et al. (1966) }\end{array}$ \\
\hline Histalog & $2.0 \mathrm{mg} / \mathrm{kg}$ & $1.5 \mathrm{mg} / \mathrm{kg} / \mathrm{hr}$ & Laudano \& Roncornoni (1965) & Wruble et al. (1967) \\
\hline Gastrin II & $\begin{array}{l}2.0 \mu \mathrm{g} / \mathrm{kg} \\
1.0 \mu \mathrm{g} / \mathrm{kg}^{*}\end{array}$ & $\begin{array}{l}67 \mu \mathrm{g} / \mathrm{hr} \\
50 \mu \mathrm{g} \dagger\end{array}$ & Makhlouf et al. (1964b) & Makhlouf et al. (1964b) \\
\hline Pentagastrin & $6.0 \mu \mathrm{g} / \mathrm{kg}$ & $1.5 \mu \mathrm{g} / \mathrm{kg} / \mathrm{hr}$ & Makhlouf et al. (1966) & Kontrurek \& Oleksy (1967) \\
\hline Tetragastrin & $20 \cdot 0 \mu \mathrm{g} / \mathrm{kg}$ & - & Koster et al. (1968) & - \\
\hline Insulin (crystaline) & - & $\begin{array}{r}0.15 \text { units } / \mathrm{kg} \\
60 \cdot 20 \text { units } / \mathrm{kg} \\
0.25 \text { units } / \mathrm{kg}\end{array}$ & - & $\begin{array}{l}\text { Duke et al. (1965), Hubel (1966), } \\
\text { Kalmark \& Obrink (1967) }\end{array}$ \\
\hline 2-Deoxy-D-glucose & - & $50 \mathrm{mg} / \mathrm{kg}$ & - & Johnston et al. (1967) \\
\hline
\end{tabular}

using the recommended doses (Table 2), is comparable with that observed with any other stimulus but the values are not identical (Ward et al., 1963; Makhlouf et al., 1965; Hubel, 1966; Koster et al., 1968).

\section{Dose of the stimulus}

The dose of a stimulus-histamine (Kay, 1953), histalog (Laudano \& Roncoroni, 1965), gastrin II (Makhlouf et al., 1964a), pentagastrin (Makhlouf et al., 1966), tetragastrin (Koster et al., 1968) and insulin (Duke et al., 1965; Hubel, 1966; Johnston et al., 1967)-is calculated in relation to body weight. Kay (1953) had shown that the minimal dose of histamine acid phosphate which causes MAO is $40 \mu \mathrm{g} / \mathrm{kg}$ body weight and this observation was confirmed in another study from Britain (Murray et al., 1957). However, in a study from India, it was recently observed that this dose of histamine provides an inadequate stimulus to the PCM of subjects weighing less than $60 \mathrm{~kg}$ (Desai et al., 1967a) and hence the dose-weight relationship is invalid in underweight subjects. To provide adequate stimulus to the PCM of 'underweight' subjects, much larger doses of histamine calculated on body weight $(0.076 \mathrm{mg} / \mathrm{kg}$ body weight) were administered (Raghavan, Acharya \& Pimparkar, 1967). However, administration of very large doses of any stimulus is not advisable as a supramaximal dose of gastrin (Emas \& Grossman, 1967a; Gillespie et al., 1967; Konturek \& Oleksy, 1967), insulin (Olson \& Nechleles, 1953) or histamine (Desai et al., unpublished observation 1968) causes reduction in acid output. Recently, fixed doses of histamine acid phosphate $(2.4 \mathrm{mg}$ for control subjects and $2.8 \mathrm{mg}$ for patients with duodenal ulcer) were recommended as providing an adequate, safe and not supramaximal stimulus to the PCM of subjects with widely different body weights (Desai et. al., 1968c and unpublished observation).

\section{Route of administration}

Histamine, histalog, gastrin and pentagastrin are administered subcutaneously or intravenously (Table 2). In contrast to subcutaneous tests, infusion tests provide a steady maximal stimulus and hence values of acid output are significantly higher with the latter (Lawrie \& Forrest, 1965). Another advantage of the infusion test is that any error of collection after reaching a 'steady rate' is obvious and can be rectified.

\section{Synergistic action of another stimulus}

Administration of mecothane or pentagastrin with histamine will show much higher values of acid secretion than the MAO observed with histamine alone (Makhlouf et al., 1965; Konturek \& Oleksy, 1967). This observation suggests that the MAO observed with any one stimulus is maximal for the conditions of that experiment only and different stimuli probably have different mechanisms of stimulating parietal cell.

\section{Electrolyte levels}

\section{Serum calcium}

Intravenous infusions of calcium result in an immediate increase in MAO in control subjects (Donegan \& Spiro, 1960; Ward, Adesola \& Welbourn, 1964; Murphy et al., 1966; Barreras \& Donaldson, 1967a, b). Since no correlation was observed between acid output and serum calcium levels (Smallwood, 1967) and acid secretion did not diminish in patients with hyperparathyroidism after 
removal of a parathyroid tumour (Donegan \& Spiro, 1960 ), it was suggested that a sharp rise in calcium following an acute calcium load rather than the actual calcium levels causes an increase in acid secretion (Smallwood, 1967). Furthermore, abolition of the gastric secretory response to intravenous infusion of calcium salts by atropine or vagotomy suggests that serum calcium increases acid secretion by affecting the vagal stimuli (Barreras \& Donaldson, 1967a; Smallwood, 1967).

\section{Serum chloride}

Withdrawal of salt from the diet or the administration of frusemide caused a significant fall in acid output both on AHT and HIT (Kothari et al., 1969); in all probability this occurred as a result of lowering of serum chloride levels. Furthermore, administration of normal saline by infusion was also noted to cause a significant increase in acid output (Barreras \& Donaldson, 1967b).

\section{Anaemia}

Low values of acid output both on AHT and HIT have been reported in iron deficiency anaemia (Ikkala \& Siurala, 1964; Cowan et al., 1966; Dagg et al., 1966; Jacobs et al., 1966; Desai et al., 1967c) and megaloblastic anaemia (Cowan et al., 1966). In some patients, the values of MAO were significantly raised on correction of anaemia after about 6-8 weeks (Desai et al.,1968b).

Iron-dependent enzyme system: The observation that acid output increased in some patients within 2-3 days (i.e. before correction of anaemia) after intravenous infusion of iron suggests that elemental iron itself increases acid secretion, probably by influencing some iron-dependent enzyme system (Desai et al., 1968b).

\section{Hormones \\ Gastrin}

In the presence of excessive secretion of gastrin by a pancreatic tumour (Zollinger \& Ellison, 1955; Grossman, Tracey \& Gregory, 1961) or due to exclusion of the gastric antrum in the duodenal stump during operation (Scobie et al., 1964) or on administration of gastrin II (Makhlouf et al., 1964b), acid output increases markedly.

\section{Parathormone}

Injection of parathyroid hormone to control subjects increases acid secretion but acid output did not alter following operation in patients with hyperparathyroidism (Donegan \& Spiro, 1960). This observation indicates that chronic excess (in contrast to acute rise) of parathyroid hormone did not affect gastric secretion (Donegan \& Spiro, 1960; Ostrow,
Blanard \& Gray, 1960). In idiopathic hypoparathyroidism with serum calcium levels below $7.0 \mathrm{mg} /$ $100 \mathrm{ml}$, acid secretion is markedly reduced and increases on raising the serum calcium levels above this critical level (Donegan \& Spiro, 1960).

\section{Thyroxine}

In patients with hyperthyroidism, values of acid output were found to be lower than those reported for control subjects; the higher incidence of chronic gastritis on gastric biopsy in hyperthyroidism probably explains this observation (Bock \& Witts, 1963; Siurala, Julkunen \& Lamberg, 1966). However, low values were also observed in a few patients with normal gastric mucosa (Siurala et. al., 1966) and hence it was postulated that the hyperthyroid state itself inhibits vagal impulses, resulting in functional impairment of the parietal cells (Doteval, Rohrer \& Wolf, 1965). The observation that treatment of the hyperthyroid state did not increase acid secretion in the majority of subjects studied indicates that histological changes are more important (Siurala et al., 1966).

\section{Aldosterone}

In a patient with primary aldosteronism, histaminefast achlorhydria was noted pre-operatively and removal of the adrenal tumour resulted in significantly raised acid secretion (van Buchem, Doorenbos \& Elings, 1966; Ross, 1959) indicating that aldosterone directly inhibits acid secretion.

\section{Corticoids}

Administration of corticoids increases acid secretion in dogs (Clarke, Neill \& Welbourn, 1960) and in patients with atrophic gastritis (Jeffries, Todd \& Sleisenger, 1966). The increase in acid secretion is due to the increase in the number of parietal cells (Jeffries et al., 1966).

\section{Antidiuretic hormone}

Infusion of antidiuretic hormone inhibits acid secretion in dogs and this inhibition probably occurs under physiological conditions (Karlmark \& Obrink, 1967).

\section{Drugs}

Administration of larger doses of acetazolamide $(100 \mathrm{mg} / \mathrm{kg})$ intravenously depresses acid secretion by blocking the action of carbonic anhydrase (Janowitz et al., 1957; Linder et al., 1962; Ojha \& Ahmed, 1967). Mecothane or parasympathomimetic drug augments the maximal acid output observed with another stimulus (Makhlouf et al., 1965) while atropine depresses acid secretion (Johnston et al., 1966). 


\section{Vagal continuity}

Surgical or medical vagotomy reduces MAO on an average by about $60 \%$ (Gillespie \& Kay, 1961; Ross \& Kay, 1964; Bank et al., 1966; Johnston et al., 1966; Koster \& Christiansen, 1966; Payne et al., 1967). The marked reduction in acid output in the presence of the same PCM suggests that normal vagal stimuli have a very important influence on parietal cell function.

Following vagotomy, the MAO was greater with pentagastrin $(6 \mu \mathrm{g} / \mathrm{kg}$ body weight) compared with that following histamine stimulation (Bank et al., 1967). These results suggest that after vagotomy the parietal cells respond more readily to pentagastrin than to histamine (Bank et al., 1967). Since the dose-weight relationship of histamine or pentagastrin stimulation for MAO shifts to the right following vagotomy both in humans (Raju \& Narielwala, 1966; Gillespie et al., 1967) and in cats (Emas \& Grossman, 1967b), the differences observed may be related to the administration of conventional doses in relation to body weight.

\section{Parietal cell mass}

A good correlation was observed between the MAO and PCM in several studies (Card \& Marks, 1960; Marks et al., 1960; Myren \& Semb, 1962). The PCM in patients with duodenal ulcer is two to three times greater than that in control subjects (Cox, 1952). It is not yet known whether the large parietal cell mass of duodenal ulcer patients is inherited or acquired. The low values of acid secretion in children with peptic ulcer compared with adults suggest that PCM increases with age (Ghai et al., 1965). In dogs, the increase in PCM after administration of histamine was also reported (Ritchie et al., 1966). On the other hand, PCM is decreased in diseases causing destruction of fundic glands (chronic gastritis and gastric carcinoma), and acid output is diminished in such conditions (Fischermann \& Koster, 1962; Desai et al., 1968c).

\section{References}

Abernethy, R.T., Ross, R.M., Cox, A.G., Kay, A.W. \& GILLESPIE, I.E. (1967) Comparison of methods of expressing the results of augmented histamine tests. Brit. med. J. 3, 205.

BALL, P.A.J. (1961) The secretory background of gastric ulcer. Lancet, i, 1363.

Bank, S., Marks, I.N. \& Groll, A. (1966a) Gastric acid secretion in pancreatic disease. Gastroenterology, 51, 649.

Bank, S., Marks, I.N. \& Louw, J.H. (1966b) Gastric secretory patterns after vagotomy (Letter to Editor), Lancet, ii, 971.

Bank, S., Marks, I.N., Louw, J.H. \& Tigler-Wybrandi, N. (1967) Stimulation of gastric-acid secretion by histamine, pentagastrin and pentagastrin-propantheline after vagotomy in man. Lancet, ii, 67.
BARON J.H. (1963a) Studies of basal and peak acid output with an augmented histamine test. Gut, 4, 136.

BARON, J.H. (1963b) An assessment of the augmented histamine test in the diagnosis of peptic ulcer. Gut, 4, 243.

Baron, J.H. (1964) Peptic ulcer, gastric secretion and body build. Gut, 51, 83 .

Barreras, R.F. \& Donaldson, R.M., JR (1967a) Effects of induced hypercalcemia on human gastric secretion. Gastroenterology, 52, 670.

Barreras, R.F. \& Donaldson, R.M., JR (1967b) Role of calcium in gastric hypersecretion, parathyroid adenoma and peptic ulcer. New Engl. J. Med. 276, 1122.

Bock, O.A. \& WitTs, L.J. (1963) Gastric acidity and gastric biopsy in thyrotoxicosis. Brit. med. J. 2, 20.

Bruce, J., Card, W.I., Marks, I.N. \& Sircus, W. (1959) The rationale of selective surgery in the treatment of duodenal ulcer. J. Roy. Coll. Surg. Edinb. 4, 85.

Callender, S.T., Retief, F.P. \& Witts, L.J. (1960) The augmented histamine test with special reference to achlorhydria. Gut, $1,326$.

CARD, W.I. \& MARKS, I.N. (1960) The relationship between the acid output of the stomach following 'maximal' stimulation and the parietal cell mass. Clin. Sci. 19, 147.

Clarke, S.D., Neill, D.W. \& Welbourn, R.B. (1960) The effect of corticotrophin and corticoids on secretion from denervated gastric pouches in dogs. Gut, 1, 36.

Coghill, N.F. (1960) The significance of gastritis. Postgrad. med. J. 36, 733.

Cowan, B., Joseph, S. \& SatiJa, V.K. (1966) The gastric mucosa in anaemia in Punjabis. Gut, 7, 234.

Cox, A.J. (1952) Stomach size and its relation to chronic peptic ulcer. Arch. Path. 54, 407.

DagG, J.H., Goldberg, A., Gibbs, W.N. \& Anderson, J.R. (1966) Detection of latent pernicious anaemia in iron deficiency anaemia. Brit. med.J. 2, 619.

DeMoura, M.C. \& Correia, J.P (1964) Statistical analysis of gastric secretion data in normal subjects and in patients with duodenal ulcer following maximal histamine stimulation. Amer. J. dig. Dis. 9, 669.

Desai, H.G., Borkar, A.V. \& Jeejeebhoy, K.N. (1967a) Dose-weight relationship of histamine for maximal stimulation of gastric acid secretion. Gastroenterology, 53, 712.

Desai, H.G., Borkar, A.V. \& Jeejeebhoy, K.N. (1967b) Histamine-infusion test. I. Control subjects. Indian J. med. Sci. 21, 785.

Desai, H.G., Mehta, B C., Borkar, A.V. \& Jeejeebhoy, K.N. (1967c) Measurement of gastric acid secretion with histamine-infusion test in iron deficiency anaemia. Indian J. med. Sci. 55, 1051.

Desai, H.G. Borkar, A.V. \& Jeejeebhoy, K.N. (1968a) Correlation between bodyweight, acid output and parietal cell mass. Indian J. med. Res. 56, 717.

Desal, H.G., Mehta, B.C., Borkar, A.V. \& Jeejeebhoy, K.N. (1968b) Effect of intravenous iron therapy on gastric acid secretion in iron deficiency anaemia. Gut, 9, 91.

Desai, H.G., Borkar, A.V. \& JeEjeebhoy, K.N. (1968c) Correlation between gastric acid secretion and histology in Indian subjects. Scand. J. Gastroent. 3, 509.

Donegean, W.L. \& SPIRo, H.M. (1960) Parathyroid and gastric secretion. Gastroenterology, 38, 750.

Dotevall, G., Rohrer, G.V. \& Wolf, S. (1965) The relationship of thyroid function to gastric secretion (Abstract). Gastroenterology, 48, 814.

Duke, W.W., Hikschowitz, B.I. \& SAChs, G. (1965) Vagal stimulation of gastric secretion in man by 2-deoxy-Dglucose Lancet, ii, 871

Emas, S. \& Grossman, M.I. (1967a) Comparison of gastric secretion in conscious dogs and cats. Gastroenterology, 52, 29. 
Emas, S. \& Grossman M.I. (1967b) Effect of truncal vagotomy on acid and pepsin responses to histamine and gastrin in cats. Amer. J. Physiol. 213, 657.

FischermanN, K. \& Koster, K.H. The augmented histamine test in the differential diagnosis between ulcer and cancer of the stomach. Gut, 3, 211.

Ghai, O.P., Singh, M., Walia, B.N.S. \& Ghadekar, N.G. (1965) An assessment of gastric acid secretory response with 'maximal' augmented histamine stimulation in children with peptic ulcer. Arch. Dis. Childh. 40, 77.

GillesPiE, I.E. \& KAY, A.W. (1961) Effect of medical and surgical vagotomy in the augmented histamine test in man. Brit. med. J. 1, 1557.

Gillespie, I.E., McCusker, V.I., Gillespie, G., Johnston, I.D.A., SpIVey, J., AllsopP, R.H., PAyne, R.A., CoX, A.G., Vedast, M., Makin, G.S., Shivastava, S.R., Johnston, D., Jepson, K. \& Duthie, H.L. (1967) The effect of vagotomy on gastric secretion elicited by pentagastrin in man. A multicentre study. Lancet, ii, 534.

Grossman, M.I., Tracy, H.J. \& Gregory, R.A. (1961) Extraction of gastrin-like activity from tumour. Gastroenterology, 41, 87.

Hollander, F. (1946) The insulin test for the presence of intact nerve fibers after vagal operations for peptic ulcer. Gastroenterology, 7, 607.

Hubel, K.A. (1966) Insulin-induced gastric acid secretion in young man. Test reproducibility and correlation with the augmented histamine test. Gastroenterology, 50, 24.

Hume, R. \& Melrose, A.G. (1967) Relation between maximal acid output of stomach and lean body mass. Brit. med. J. 2, 30.

HussaIN, S.S. (1965) A study of gastric secretions in 1000 peptic ulcer patients. J. Ass. Phycns Ind. 13, 417.

IKKALA, E. \& Siurala, M. (1964) Gastric lesion in iron deficiency anaemia. Acta Haemat. (Basle), 31, 313.

Jacobs, A., LaWrie, J.H., EnTwistle, C.C. \& CAMPbell, H. (1966) Gastric acid secretion in chronic iron-deficiency anaemia. Lancet, ii, 190.

James, A.H. \& Pickering, G.W. (1949) The role of gastric acidity in the pathogenesis of peptic ulcer. Clin. Sci. 8, 181.

Janowitz, H.D., Dreiling, D.A., Rolbin, H.L. \& HolLANDER, F. (1957) Inhibition of the formation of hydrochloric acid in the human stomach by diamox: The role of carbonic anhydrase in gastric secretion. Gastroenterology, 33, 378.

JefFries, G.H., Todd, J.E. \& Sleisenger, M.H. (1966) The effect of prednisolone on gastric mucosal histology, gastric secretion and vitamin $B_{12}$ absorption on patients with pernicious anaemia. J. clin. Invest. 45, 803.

Johnston, D.H. \& MCGRAW, B.H. (1958) Gastric analysisEvaluation of collection techniques. Gastroenterology, 35, 612.

Johnston, D., Goligher, J.C. \& Duthie, H.L. (1966) Medical vagotomy: an assessment. Brit. med. J. 2, 1481.

Johnston, D., Thomas, D.G., Checketts, R.G. \& Duthie, H.K. (1967) An assessment of postoperative testing for completeness of vagotomy. Brit. J. Surg. 54, 831.

Karlmark, B. \& Obrink, K.J. (1967) The antidiuretic hormone as an inhibitor of gastric secretion. Scand. $J$. Gastroent. 2, 124.

KAY, A.N. (1953) Effect of large doses of histamine on gastric secretion of $\mathrm{HCL}$-an augmented histamine test. Brit. med. J. 2, 77.

Kedarnath, 0, Paul, D. \& Garg, K.C. (1965) Augmented histamine test in peptic ulcer and ulcer dyspepsia. J. Ass. Phycns Ind. 13, 627.

Kontrurek, S.J. \& Oleksy, J. (1967) Pontentiation between pentapeptide (ICI 50, 123) and histamine with stimulation of gastric secretion in man. Gastroenterology, 53, 912.
Koster, K.H., Rodbro, P. \& Peterson, H.J. (1968) Comparative effects of tetragastrin and histamine on acid and intrinsic factor secretion in man. Scand. J. Gastroent. 3, 23.

Koster, K.H. \& Christiansen, P.M. (1966) Gastric secretory patterns after vagatomy (Letter to Editor). Lancet, ii, 971.

Kothari, M.L., Doshi, J.C., Desai, H.G., Vaidya, A.B. \& SHETH, U.K. (1969) Reduction of gastric acid secretion on a low salt diet and furosemide. Gut, 10, 71.

Laudano, M. \& RoncoRnoni, E.C. (1965) Determination of the dose of histalog that provokes maximal gastric secretory response. Gastroenterology. 49, 372.

LAWrie, J.H., SMITH, G.M.R. \& Forrest, A.P.M. (1964) The histamine-infusion test. Lancet, ii, 270.

LAWrie, J.H. \& Forrest, A.P.M. (1965) The measurement of gastric acid. Postgrad. med. J. 41, 408.

Levine, E., Kirsner, J.B., PAlmer, W.L. \& Butler, C. (1948) The variability and periodicity of the nocturnal gastric secretion in normal individual. Gastroenterology, 10, 939.

Linder, A.E., Cohen, N., Dreiling, D.A. \& JANOWITZ, H.D. (1962) Effect of acetazolamide on the secretion of sodium and potassium by the human stomach. J. appl. Physiol. $17,514$.

Madangopalan, N., Subramaniam, R. \& Saroja, R. (1967) Report on augmented histamine test from Madras. J. Ass. Phycns Ind. 15, 501.

Makhlouf, G.M., MacManus, J.P.A. \& Card, W.I. (1964a) The action of gastrin II on gastric-acid secretion in man. Lancet, ii, 485.

Makhlouf, G.M., MacManus, J.P.A. \& Card, W.I. (1964b) Dose-response curves for the effect of gastrin II on acid gastric secretion in man. Gut, 5, 379.

Makhlouf, G.M., MacManus, J.P.A. \& Card, W.I. (1965) A comparative study of the effects of gastrin, histamine, histalog and mecothane on the secretory capacity of the human stomach in two normal subjects over 20 months. Gut, 6, 525.

Makhlouf, G.M., MacManus, J.P.A. \& CaRd, W.I. (1966) The action of pentapeptide (ICI 50, 123) on gastric secretion in man. Gastroenterology, 51, 455.

MARKS, I.N. \& SHAY, H. (1959) Observations on the pathogenesis of gastric ulcer. Lancet, i, 1107.

Marks, I.N., Komorov, S.A. \& Shay, H. (1960) Maximal acid secretory response to histamine and its relation to parietal cell mass in the dog. Amer. J. Physiol. 199, 579.

MurPhy, D.L., Goldstein, H., Boyle, J.D. \& WARD, S. (1966) Hypercalcemia and gastric secretion in man. J. appl. Physiol. 21, 1607.

Murray, F.A., Erskine, J.P. \& Fielding, J. (1957) Gastric secretion in pregnancy. J. Obstet. Gynec. Brit. Commwlth, 64, 373.

MYREN. J. \& SEMB, L.S. (1962) The number of parietal cells and the rate of gastric secretion before and after subcutaneous injection of large doses of histamine. Gastroenterologia, 98, 207.

OjhA, K.N. \& Ahmed, Q. (1967) The inhibitory effect of some thiazide diuretics and acetazolamide on the histamine induced gastric secretory response in pigeons. Ind. J. Physiol. Pharmacol. 11, 53.

Olson, W.H. \& Necheles, H. (1953) Initial depression of human gastric secretion by insulin. Gastroenterology, 24, 362 .

Ostrow, J.D., Blanchard, G. \& Gray, S.J. (1960) Peptic ulcer in primary hyperparathyroidism. Amer. J. Med. 29, 769.

Payne, R.A., Cox, A.G., Spencer, G. \& Cheng, F.C.Y. (1967) Effect of vagotomy on gastric acid secretion stimulated by pentagastrin and histamine. Brit. med. $J$. 2, 456.

Raghavan, P., Acharya, U.N. \& Pimparkar, B.D. (1967) Nocturnal secretion studies in duodenal ulcer. Ind. J. med. Res. 55, 109. 
Raju, S., Ganguly, P.C., Bhat, H.S. \& Narielwala, P.M. (1965) The place of augmented histamine test as a study of gastric acid secretion. J. Ass. Phycns Ind. 13, 399.

RaJu, S. \& Narielwala, F.M. (1966) Acid secretory response to graded doses of histamine after 'medical vagotomy'. Gut, 7, 474.

Ritchie, W.P. JR, Delaney, J.D., Barxilai, A., Lande, A.J. \& WANGesteen, O.H. (1966) Experimental alterations in gastric mucosal cellular population in dogs. J. Amer. med. Ass. 197, 153.

Rosiere, C.E. \& Grossman, M.I. (1951) An analog of histamine that stimulates gastric acid secretion without other actions of histamine. Science, 113, 651.

Ross, B. \& KAY, A.W. (1964) The insulin test after vagotomy Gastroenterology, 46, 379.

Ross, E.J. (1959) Aldosterone. Clinical and Experimental Medicine, p. 90. Blackwell Scientific Publications, Oxford.

Scobie, B.A., McGill, D.B., Priestley, J.T. \& Rovelstad, R.A. (1964) Excluded gastric antrum simulating the Zollinger Ellison Syndrome. Gastroenterology, 47, 184.

Siurala, M., Julkunen, H. \& Lamberg, B.A. (1966) Gastrointestinal tract in hyperthyroidism before and after treatment. Scand. J. Gastroent. 1, 79.

Smallwood, R.A. (1967) Effect of intravenous calcium administration on gastric secretion of acid and pepsin in man. Gut, 8, 592.
Thomas, D.G. \& Duthie, H.L. (1968) Use of 2-deoxy-Dglucose to test for the completeness of surgical vagotomy. Gut , 9, 125.

Vakil, B.J. \& MulekaR, A.M. (1965) Studies with maximal histamine test. Gut, 6, 364.

Van Buchem, F.S.P., DCorenbos, H. \& Elings, H.S. (1956) Conn's syndrome caused by adrenocortical hyperplasia. Acta endocr. (Kbh.), 23, 313 (cited by Ross, 1959).

Ward, S., Gillespie, I.E., Passaro, E.P. \& Grossman, M.I. (1963) Comparison of histalog and histamine as stimulants for maximal acid secretion in human subjects and in dogs. Gastroenterology, 44, 620.

Ward, J.T., Adesola, A.O. \& Welbourn, R.B. (1964) The parathyroids, calcium and gastric secretion in man and the dog. Gut, 5, 173.

WiLLIAMS, A.W. (1950) The stomach of the recently deceased. Brit. med. J. 1, 102.

Wruble, L.D., Cummings, A.J., Goldenberg, T. \& SchaPIRO, H. (1967) The effect of intravenous histalog on gastric secretion in man. Amer. J. dig. Dis. 12, 1087.

Zollinger, R.M. \& Ellison, E.H. (1955) Primary peptic ulcerations of the jejunum associated with islet cell tumours of the pancreas. Ann. Surg. 142, 709.

\title{
The lumbar disc syndrome
}

\author{
John Pearce \\ M.D., M.R.C.P. \\ Combined Neurological Service, \\ Hull Royal Infirmary
}

Clinical syndromes resulting from the protrusion of disc material into the spinal canal have been recognized since the original description of Dandy (1929) and the classical paper of Mixter \& Barr in 1934. Despite intensive study, the precise aetiology of degeneration of the intervertebral discs remains obscure. Many factors of contributory importance have been identified. With progressive ageing, there is a gradual loss of water content of the nucleus pulposus, rendering this structure more friable and prone to degeneration. Similarly there is a progressive loss of elastic tissue and replacement fibrosis of the annulus fibrosus, and hence this structure will succumb more easily to any sudden rise of pressure in the nucleus pulposus. These changes commence after adolescence, but are undoubtedly aggravated by repeated minor trauma. Thus, lumbar disc lesions tend to be more common in heavy manual workers involved in repeated bending and lifting, and particularly are related to the repeated back injuries, so common in miners. Although trauma is often an important factor, lumbar disc protrusions are undoubtedly quite common in sedentary workers, and it is customary to blame faulty posture of the back, lack of exercise and unaccustomed domestic physical exertion in such patients. The frequent occurrence of disc lesions in pregnancy is probably attributable to the hydraemia of pregnancy which indirectly weakens the ligamentous support of the intervertebral disc, and may lead to its expansion.

\section{Pathology}

Fig. 1 shows the normal intervertebral disc in sagittal and horizontal section and illustrates the proximity of the intervertebral foramen which contains the nerve root and artery, to the annulus fibrosus. Fig. 2 shows the stages in prolapse of an intervertebral disc. In the first stage the annulus is torn but there has been no extrusion of the nucleus pulposus. Shortly after this the nuclear material is 